\title{
Are urgența regulile ei?
}

conf. univ. dr. Radu Rizoiu

Facultatea de Drept, Universitatea București

Motto: State of emergency

How beautiful to be

State of emergency

Is where I want to be ${ }^{1}$

Rezumat: Articolul redeschide faimoasa dispută referitoare la „starea de excepție” din perspectiva cetățeanului. Este oare legiuitorul imun la regula pe care el însuși a edictat-o? Textul observă că regula trebuie să fie respectată in primul rând de către cel care a edictat-o tocmai pentru a oferi și celorlalți un exemplu de urmat. Este analizată de asemenea tensiunea dintre respectarea regulii și nevoia de a impune sancțiuni pentru nerespectarea regulii. În fapt, nicio regulă nu poate fi calificată ca una care îndeamnă la respectare sau care necesită impunere prin sancțiune, dar trebuie găsită combinația corectă între cele două elemente. In plus, sancțiunea trebuie să fie proporțională cu gravitatea încălcării. În acest fel se poate asigura un sistem juridic stabil.

Cuvinte-cheie: reguli, stare de urgență, preeminența dreptului

\section{Has the emergency its own rules?}

Abstract: The paper reopens the famous dispute on the 'state of exception' from a citizen's perspective. Is the rule-giver immune to the rule he enacted? The finding is that the rule should be observed by the ruler in the first place in order to give an example to the others. Also, it is explored the dialectic tension between the self-respecting rules and rules that needs to be sanctioned by the State's agents. While no rule could be placed in one single category, it is the right combination between drafting rules easy to comply with and imposing penalties proportionate with the infringement that will ensure a stable legal system.

Keywords: rules, state of emergency, rule of law

Prietenul la nevoie se cunoaște; regula în urgență se vede. Spre deosebire de opinia care spune că starea de excepție reprezintă o suspendare a legii ${ }^{2}$, vedem în aceste zile cum regulile devin mai importante ca oricând într-o țară care își dorește să evite anarhia. De la sfaturi care ne explică în ce fel atitudinea „merge și așa”3 poate fi una care să ne expună pericolului, până la ordonanțe de urgență care să ne explice cum se aplică reguli existente, vedem că regulile (re)vin în prim-planul opiniei publice. Colegii mei au început deja să explice cum arată legile în stare de

\footnotetext{
${ }^{1}$ Björk, Jóga, „Homogenic” (1997)

${ }^{2}$ Giorgio Agamben, Starea de excepție (Homo sacer II, 1), editura IDEA Design \& Print, Cluj-Napoca, 2008.

3 A se vedea știrea despre măștile improvizate, la adresa http://www.monitorulcj.ro/actualitate/78752-ministerulsanatatii-avertizeaza-ma\%C5\%9Ftile-fabricate-manual-sau-din-panza-bumbac-tifon-nu-protejeaza-impotrivainfec\%C5\%A3iei-cu-coronavirus.
} 
urgență, ca izvoare normative ${ }^{4}$, respectiv cum se modifică politica penală pentru a asigura respectarea unor reguli care au fost considerate desuete ${ }^{5}$. Eu voi încerca să semnalez unele chestiuni (mai) generale despre cum funcționează regulile, iar starea de urgență pare a pune sub lumina reflectoarelor unele trăsături ale regulilor pe care de multe ori le ignorăm.

\section{Fă ce spune popa, nu ce face popa}

Un întreg curent de gândire (asociat, de regulă, pozitivismului postbelic ${ }^{6}$ ) folosește calitatea emitentului drept criteriu de identificare a normelor juridice din noianul cotidian de reguli. Dacă regula este „spusă” de o anumită instituţie, urmând o anumită procedură, atunci ea devine lege. Puterea normativă este astfel asociată cu un ,ritual” care dă o forță specială unei reguli (propoziții performative). În termenii folosiți de ,inițiați”, suveranitatea aparține poporului [art. 2 Const.], care o exercită prin aleșii săi, iar legea este o manifestare a suveranității. De vreme ce Parlamentul este privit ca principala formă de exercitare a suveranității [art. 61 alin. (1) Const.] (între consultările populare), actele emise de el (după o anumită procedură [art. 73-78 Const.]) sunt legi.

În mod excepțional (iar starea de urgență este o astfel de excepție), și Guvernul poate adopta acte normative similare legii (ordonanțele). Și aici trebuie urmată o anumită procedură și ne $\operatorname{amintim}^{7}$ că, oricât de (formal) exact se respectă această procedură, voința populară poate să cenzureze un act normativ in nuce. În același timp, Curtea Constituțională ne amintește ${ }^{8}$ că, deși doar Parlamentul este autoritatea legislativă prin excelență, delegarea legislativă este cel puțin la fel de justificată. $\mathrm{Nu}$ trebuie uitat însă faptul că toate aceste mecanisme au și dispozitive de siguranţă: deciziile administrative pot fi cenzurate de instanţele de contencios administrativ, calitatea legii este verificată constant de către Curtea Constituțională.

Acum vedem că și Președintele poate legifera [art. 93 Const.]. Și el trebuie să obțină o confirmare din partea Parlamentului, dar aceasta survine ex post, după ce actul normativ a fost deja adoptat. Citind recentul Decret nr. 195/2020 privind instituirea stării de urgență pe teritoriul României, observăm că el cuprinde o serie întreagă de prescripții normative directe, plus direcții de acțiune care permit anumitor autorităţi administrative să adopte alte norme.

Rămâne însă întrebarea, orice spune legea (Parlamentul, Guvernul, Președintele) este obligatoriu? Celebra afirmație a Sfântului Toma din Aquino (lex injusta non est lex) ${ }^{9}$, readusă în

4 Bogdan Dima, Starea de urgență va fi constituțională sau nu va fi deloc, disponibil la adresa https://drept.unibuc.ro/dyn_img/aubd/Starea\%20de\%20urgen\%C8\%9B\%C4\%83\%20va\%20fi\%20constitu\%C8\%9B ional\%C4\%83\%20sau\%20nu\%20va\%20fi\%20deloc.pdf.

${ }^{5}$ George-Alexandru Lazăr, Modificările propuse pentru modificarea Codului Penal în vederea combaterii răspândirii coronavirusului, disponibil la adresa https://drept.unibuc.ro/dyn_img/aubd/Modifica\%CC\%86rile\%20aduse\%20Codului\%20Penal\%20prin\%200rdonant $\%$ CC\%A6a\%20de\%20Urgent\%CC\%A6a\%CC\%86.pdf.

${ }^{6}$ Principalul promotor a fost H.L.A. Hart (The Concept of Law, Clarendon Press, Oxford, 1994), dar și Ronald Dworkin (Law's Empire, Harvard University Press, Cambridge, 1986) a fost „,convins” de această idee.

7 Pentru o analiză normativă a evenimentelor din februarie 2017, a se vedea R. Rizoiu, Puțin realism nu strică, disponibil la adresa https://www.juridice.ro/essentials/902/putin-realism-nu-strica.

${ }^{8}$ Curtea Constituțională, Decizia nr. 68/2017 referitoare la cererea de soluționare a conflictului juridic de natură constituțională dintre Guvernul României și Ministerul Public - Parchetul de pe lângă Înalta Curte de Casație și Justiție - Direcția Națională Anticorupție, cerere formulată de Președintele Senatului.

${ }^{9}$ Pentru unele analize contemporane, a se vedea Norman Kretzmann, Lex Iniusta Non Est Lex - Laws on Trial in Aquinas' Court of Conscience, în „The American Journal of Jurisprudence” vol. 33, nr. 1/1988, p. 99-122; J.S. Russell, Trial by Slogan: Natural Law and Lex Iniusta Non Est Lex, în „Law and Philosophy” vol. 19, nr. 4/2000, p. $433-449$. 
atenția modernității de Martin Luther King jr. și discutată pe larg de profesorul Marian Nicolae ${ }^{10}$, demonstrează că teza pozitivistă trebuie asezonată cu elemente de drept natural ${ }^{11}$. Altfel spus, așa cum a remarcat și Curtea Europeană a Drepturilor Omului, ,justice must not only be done, it must also be seen to be done"12, iar același lucru ar putea fi spus în general despre lege. Așadar, dacă un exponent al puterii publice ignoră o lege, va mai fi acea lege respectată de restul lumii? Câtă vreme încălcarea legii este o simplă deviere de la comportamentul normal (așteptat) și, deci, este sancționată ca atare, Universul va rămâne la locul lui. Nu contează cine a încălcat legea, el trebuie să sufere rigorile asociate de acea lege cu faptele sale, căci, nu-i așa, „,[n]imeni nu este mai presus de lege" [art. 16 alin. (2) Const.].

Am văzut în ultimele zile astfel de exemple. Poate cel mai mediatizat a fost cel al fostului angajat al Ministerului de Interne (actualmente angajat al unei autorități publice locale) care a ascuns cu intenție ${ }^{13}$ faptul că a venit dintr-o zonă periculoasă și, în consecință, nu a urmat regulile privind izolarea la domiciliu. Iată un funcționar public care a considerat că „știe el mai bine” și a ales să nu respecte legea. Iar în final legea i s-a aplicat. Dar oare câți au făcut la fel și nu au fost „prinși”?

Un alt fapt a scăpat însă unei analize normative, în iureșul evenimentelor. La un moment dat, în primele etape ale crizei (încă nu se decretase starea de urgență, dar deja existau reguli privind autoizolarea), întregul Guvern a fost suspectat de infectare cu virusul COVID-19. Ce a făcut atunci Guvernul (în plenul său, deci fiecare membru al Guvernului)? Au ales să ignore regula pe care tot ei o instituiseră și au ținut o ședință de Guvern pe care au și difuzat-o pe toate canalele mediatice ${ }^{14}$. O țară întreagă a putut să vadă că se poate evita izolarea dacă îți pui o mască medicală pe faţă și încerci să stai la două scaune distanță de celălalt. Iar Parlamentul a făcut la fel atunci când a audiat membrii noului (aceluiași?) Cabinet. Apoteoza a constat în ceremonia (!) de învestitură de la Palatul Cotroceni când aceleași persoane au stat în prezența Președintelui. Același Președinte care după doar câteva zile a decretat starea de urgență... Iată cum, în câteva zile, toate autoritățile „legiuitoare” au reușit să încalce legea! Mai mult, toate aceste încălcări s-au făcut în lumina reflectoarelor și aplauzele milioanelor de (tele)spectatori.

Aceste fapte ridică o întrebare: oare ce forță mai are legea atunci când este încălcată ,în plină zi" ${ }^{15}$ tocmai de către cei care au adoptat-o? Videoclipurile cu diferite figuri publice care ofereau sfaturi despre măsurile de distanțare socială în fața unei mulțimi (de reporteri) pentru ca

\footnotetext{
${ }^{10}$ Marian Nicolae, Drept civil. Teoria generală, vol. I, Teoria dreptului civil, editura Solomon, București, 2017, p. 239-240.

${ }^{11}$ Fuller, în celebra sa dispută cu Hart, a folosit și acest argument. A se vedea Lon Fuller, The Morality of Law, revised edition, Yale University Press, New Haven, 1969, passim, în special p. 91-92 (coerenţa dintre ceea ce spune legiuitorul și ceea ce face) și p. 123 (problema legilor imorale).

${ }^{12}$ CEDO, Cauza GHULYAN c. ARMENIA, Cererea nr. 35443/13, secția I, hotărârea din 24 ianuarie 2019, §46. Fraza originară „Not only must Justice be done; it must also be seen to be done” a apărut în celebra cauză a Curții Supreme din Anglia în cauza $R$ v Sussex Justices, ex parte McCarthy ([1924] 1 KB 256, [1923] All ER Rep 233).

${ }^{13}$ Din punct de vedere moral poate fi interesantă analiza motivelor subiective care 1-au făcut să mintă, dar în plan juridic intenția rămâne [art. 16 alin. (2) NCC].

${ }^{14}$ Iar exemplul care arată cât de departe poate merge lipsa de înțelegere a funcționării regulilor este cel al conferinței de presă ținută în prezența fizică a reporterilor, unde premierul a anunțat că sunt toți membrii Guvernului suspecți de infectare și vor intra în carantină...

${ }^{15}$ În dreptul penal, o infracțiune comisă ziua pare mai puțin reprobabilă decât una comisă „noaptea, ca hoții”, dar o faptă săvârșită în public (re)devine mai periculoasă social. În termenii dreptului penal, săvârșirea în timpul nopții şi săvârșirea în public sunt, de regulă, circumstanțe agravante.
} 
în timpul sfaturilor să le încalce au făcut deliciul publicului. Dar ele arată că regula ajunge să cadă în derizoriu ${ }^{16}$. Râdem de contravenient sau de idealismul regulii?

\section{Conformarea voluntară și sancționarea instituțională}

O celebră dispută privește rolul regulilor: sunt ele edictate în vederea respectării lor sau pentru a permite sancționarea contravenienților? Subiectul este extrem de controversat. Dacă ele sunt simple prescripții despre cum trebuie să acționezi, atunci se are în vedere conformarea voluntară. Dacă asta se urmărește, atunci regulile trebuie concepute în așa fel încât să aibă în vedere comportamentul spontan cel mai frecvent ${ }^{17}$ și să pună la dispoziție mijloace dintre cele mai facile pentru a asigura respectarea regulii ${ }^{18}$. Aici se mizează pe ,zăhărelul"19 convingerii subiectului regulii că este în avantajul lui să o respecte. Această teorie pleacă de la premisa că oamenii sunt principial buni și că au doar nevoie să fie ,păstoriți” pentru a vedea „lumina”. Sfântul Apostol Pavel, în Epistola către romani pare a pleda către această teorie.

Dacă, din contră, se urmărește crearea condițiilor pentru a-i putea sancționa pe cei care nu respectă un anumit cod de comportament, atunci filosofia se schimbă. Nulla poena sine lege avem nevoie de o incriminare (clară) ca să putem pedepsi. Rolul regulii este acela de a permite represiunea. Este situația polițistului care „stă în ambuscadă” pe o porțiune de drum unde viteza este drastic limitată (deși condițiile de trafic nu o justifică) pentru a ,încasa amenzi”" ${ }^{20}$. O astfel de atitudine generează o reacție instinctivă a subiectului de a găsi mijloace de a evita sancțiunea, chiar dacă încalcă regula. Se intră într-o cursă ,de-a șoarecele și pisica” în care cel care verifică respectarea legii și cel care o încalcă caută mijloacele de a-și atinge obiectivele. Să ne imaginăm de ce aplicaţia Waze are un succes mult mai mare decât cea similară a aceluiași producător, Maps: prima are ,avantajul competitiv" că îți arată unde se află amplasate echipajele de poliție care verifică respectarea regulilor în trafic; în acest fel, ea permite șoferilor să evite sancționarea și, în același timp, să ignore regulile pe porțiunile de drum ,nesupravegheate" ${ }^{21}$. Fiecare consideră acțiunile sale legitime și se ajunge într-un cerc vicios. Regula nu mai este respectată pentru că este internalizată, ci doar de frica de sancțiune. Aici vedem „,nuiaua” din mitul Sfântului Nicolae ${ }^{22}$. Adepții acestei teorii ajung la generalizări de tipul ,românul nu știe decât de frică”, pe care le recunoaștem ca aparținând curentului „,copilul trebuie bătut că altfel nu înțelege”.

Mi se pare că această a doua teorie este una care, pe termen lung, duce la mai multe pierderi decât câștiguri. Am trăit într-o epocă în care multe reguli erau respectate doar pentru că ne temeam

\footnotetext{
${ }^{16}$ Uneori ating pragul ridicolului anecdotic, precum legenda urbană a individului care, știindu-se în carantină, și-a chemat prietenii să bea o bere la el, de vreme ce el nu putea sa iasă din casă.

17 Ceea ce ridică problema protecției minorităților: dacă transformăm comportamentul majoritătiii în regulă (obligatorie), nu defavorizăm minoritatea?

${ }^{18}$ Altfel spus, regulile trebuie să fie ușor de respectat; orice complicații birocratice trebuie reduse la minim pentru a evita o reacție de respingere de tipul „este prea complicat”. Exemplul tipic este găsit în dreptul fiscal: dacă ai o procedură de plată a taxelor foarte complicată, rata de neconformare este mare. Când permiți plata din orice loc şi cu o formalizare minimă, încasările cresc (dar personalul implicat ar trebui să scadă...).

${ }^{19}$ Pentru adepții teoriilor anglo-saxone, este vorba despre „morcov” (carrot).

${ }^{20}$ Exemplul este prezentat în mod special în tușe groase, pentru a arăta că și atunci când sancțiunea este justificată şi proporțională, ajunge să fie percepută ca fiind abuzivă și în consecință încercăm să o evităm.

${ }^{21}$ Toți cei care circulă pe DN1 între București și Ploiești au dezvoltat un reflex de a frâna înainte de pasarelele unde sunt montate camere video de supraveghere a traficului, după care accelerează la „viteza de croazieră” imediat ce au depășit „obstacolul”. Uneori, simpla prezență a unui echipaj de poliție pe autostradă poate cauza ambuteiaje și accidente din partea șoferilor care frânează brusc (mult) sub viteza maximă permisă, , just in case".

22 Pentru adepții teoriilor anglo-saxone, este vorba despre „băț” (stick).
} 
de reacția autorităților. Pot mărturisi că într-un stat totalitar mare parte din ingeniozitatea umană era folosită pentru evitarea acestor reguli. Și niciun sistem represiv nu poate lupta pe termen lung cu imaginația unei întregi populații. Pe de altă parte, nici o abordare ,,pură” în care se asigură respectarea regulilor doar , cu vorba bună” nu este mai puțin idealistă. Soluția trebuie să îmbine ambele tehnici, în proporții variabile și atent dozate. În principal, trebuie adoptate reguli care permit o facilă conformare voluntară. Acolo unde există zone de neacceptare, trebuie întâi adoptată o atitudine moralizatoare: „nu este bine ce ai făcut, pentru că...”. În termeni juridici, este vorba despre aplicarea sancțiunii avertismentului (sau mustrării) ca primă reacție la încălcarea unei reguli. Abia ca ultim resort ar trebui să se apeleze la sancţiunea propriu-zisă.

Cum schimbă starea de urgență aceste teorii? Păi în primul rând măsurile adoptate trebuie să fie ușor de respectat. Dacă îi spui omului doar că trebuie să se izoleze 14 zile în propria casă, dar el nu are o casă sau nu poate să se (auto)întrețină, regula va fi încălcată cu siguranță mai devreme sau mai târziu. Așadar, ar trebui identificate și servicii de facilitare de aplicare a reguliii ${ }^{23}$. De exemplu, am un prieten izolat acasă și căruia rudele îi aduc cele necesare și le lasă la ușă. Dar nu știe ce poate face cu deșeurile rezultate. Poate oare să părăsească locuința pentru a le duce la lada de gunoi? Oare acele reziduuri nu ar trebui să aibă un „,traseu” special? Pot fi ele amestecate cu restul deșeurilor menajere? Întrebări la care marele legiuitor nu s-a gândit, ele fiind triviale ${ }^{24}$.

Unde se plasează în acest context modificările de politică penală care sunt îndreptate către majorarea limitelor de pedeapsă pentru fapte care în timpuri „normale” ar fi fost (mai mult) ignorate? Se vorbește astăzi despre pedepse exemplare menite să „bage spaima” în contravenienți. Sunt ele o soluție? Pe termen scurt pot avea un efect disuasiv, dar nu vor funcționa pe termen $\operatorname{lung}^{25}$. În plus, o persoană căreia i se aplică o astfel de pedeapsă exagerată se va simți persecutată ${ }^{26}$ pentru că a fost prima care a fost prinsă săvârșind fapta nu pentru că a comis cea mai gravă faptă. Așadar, sancțiunea nu trebuie (neapărat) înăsprită ${ }^{27}$, ci trebuie aplicată cu consecvenţă. Atunci când nu una, ci zeci de persoane sunt sancționate (nu foarte drastic, dar vizibil), conformarea voluntară va crește, iar reacția socială se va îndrepta către solidaritate cu autoritățile. Cei apropiați vor fi primii care îi vor explica prezumtivului contravenient că nu îl lasă să facă ce și-a propus (sau că vor sesiza autoritățile dacă încălcarea se produce/repetă).

\section{Fiecare pe cont propriu: Închidem țara?}

\footnotetext{
${ }^{23}$ Deja, art. 8 din Ordonanța militară de urgență nr. 2/2020 care impune autorităților să aibă grijă de persoanele aflate în nevoie se plasează pe această linie.

${ }^{24}$ Profesorul Valeriu Stoica are o celebră abordare a „gunoiului” din perspectiva actualității ocupațiunii în dreptul modern (Drept civil. Drepturile reale principale, vol. 2, editura Humanitas, București, 2006, p. 196-212).

${ }^{25}$ Dar avem nevoie ca o măsură luată pentru o stare de urgență să funcționeze pe termen lung? Nu este starea de urgență una scurtă (în raport cu perioada lungă pe care o luăm în considerare când facem legi)? Problema este exacerbată de actuala situație, dar ea poate fi analizată și în contextul legilor „,normale”.

${ }^{26}$ Trebuie să precizăm că și acest argument este doar pus în evidență de starea de urgență, iar nu specific acesteia. Ne pasă în mod special de cum se simte persecutat pentru că frustrarea și-o va manifesta (și) față de situația de urgență (deci la pandemie, dacă se supără cetățeanul că nu îl lași la terasă, nu doar că se supără pe stat, dar se gândește că pandemia e o prostie care îi limitează drepturile).

${ }^{27}$ Și aici este o chestiune general valabilă, nu neapărat specifică situațiilor de criză. Mai mult, o abordare rezonabilă este să considerăm că pedepsele sunt calculate în funcție de prejudiciul creat. Acțiunea care are o anumită pedeapsă în situații normale (și care este, deci, proporțională cu daunele create atunci) va crea daune diferite în situații de criză. Deci dacă prejudiciul este mai mare, oare nu e rezonabil să fie și pedeapsa înăsprită? Mai ales dacă acceptăm ca premisă faptul că măsura nu trebuie să fie fezabilă pe termen lung (ci doar pe durata urgenței).
} 
În ultima vreme, toate forumurile juridice au fost inundate de „descoperirea” forței majore și de disecarea unui text care până acum era studiat doar în anul II de facultate, într-o paranteză la teoria generală a obligațiilor. Chiar și legiuitorul a simțit nevoia să se preocupe îndeaproape de această instituție în contextul stării de urgență. Art. X alin. (3) din OUG 29/2020 vine tocmai în contextul în care ideea de forță majoră „legală” începuse să fie „cuvântul de ordine” în piață. Din cele patru condiții puse de art. 1351 alin. (2) NCC părea că nimic nu mai contează, cu excepția stării de urgență. Simpla existență a Decretului nr. 195/2020 era suficientă pentru a justifica forța majoră generalizată la nivelul întregii țări.

Atitudinea seamănă cu cea a elevilor care s-au bucurat că nu mai au școală și au înțeles din acest fapt că intră într-o vacanță avant la lettre. Glumele făcute de adulţi despre situațiile hilare generate de experiența de stat acasă cu copiii demonstrează că nu toată lumea pare să se bucure de această „vacanță”... În termeni normativi, vacanța ar semnifica o formă malignă de anarhie, o zonă de anomie. În momentul în care toată lumea ar invoca forța majoră, nediferențiat, atunci toate contractele ar fi suspendate de facto. Or, contractele nu sunt decât instrumente care formalizează în plan juridic diferitele relații dintre oameni. Dacă suspendăm aceste relații ajungem într-o logică a lui „scapă cine poate”. Cine ne va mai vinde făină (cine o va mai produce și depozita, în primul rând) și cine ne va mai lua gunoiul de pe stradă? Chiar și îngrijirea bolnavilor se face tot pe bază de contract...

În acest context, coeziunea socială însăși este amenințată. Este drept că anumite acțiuni sunt obiectiv împiedicate de măsurile impuse de autorități. Doar aceste acțiuni ar trebui să fie afectate de forța majoră. Sensul forței majore nu este acela de a „distruge” forța obligatorie a contractului, ci de a evita situații de angajare a răspunderii în lipsa vinovăției. Dar vina poate îmbrăca și forma culpei celei mai ușoare (culpa levissima) [art. 16 alin. (3) NCC]. Iar în cazul profesioniștilor standardul de acțiune este superior celui cerut neprofesioniștilor [art. 1480 alin. (2) NCC]. Or, când acesta din urmă este raportat la omul prudent și diligent (bonus pater familias) [art. 1480 alin. (2) NCC], ceva superior nu poate fi decât o persoană extrem de prudentă (până la limita paranoiei) și de diligentă (până la limitei tulburării obsesiv-compulsive) - un optimus pater familias. Ori de câte ori profesionistul poate găsi mijloace de a-și desfășura activitatea în noile condiții restrictive, el va trebui să o facă. Putem observa o aplicație în același art. X, în alin. (6) și (7). Forța majoră este un eveniment excepțional și trebuie să rămână așa. Altfel el ar putea conduce la o disoluție socială. Orice caz particular (obligație contractuală) trebuie analizat în contextul forței majore în mod individual. Doar dacă el întrunește toate condițiile impuse de lege, neexecutarea va putea fi scuzabilă (și, de regulă, doar temporar) ${ }^{28}$. Regula (!) rămâne că obligațiile se execută (la timp) [art. 1516 alin. (1) NCC].

Regulile continuă să se aplice chiar și în starea de excepție (urgență). Unele chiar devin mult mai vizibile. Urgența nu suspendă aplicarea regulilor, ci doar aplică anumite corecții (unele în sensul reducerii forței normative, dar majoritatea în sensul sporirii acesteia și a reacției față de încălcarea regulilor) sistemului de reguli are alcătuiesc dreptul obiectiv. Starea de urgență mai

\footnotetext{
${ }^{28} \mathrm{Nu}$ ne interesează aici alte mijloacele specifice, precum impreviziunea, excepția de neexecutare, riscul contractului sau executarea obligațiilor imposibile.
} 
degrabă subliniază importanța regulilor, iar înmulțirea mașinilor de poliție din oraș în ultimele zile $^{29}$ ilustrează tocmai acest mesaj al statului: legea continuă să se aplice!

De fapt, urgența este acel moment în care energiile individuale trebuie conservate dacă nu sunt orientate către necesitățile de bază. Deși pare că urgența accelerează acțiunile individuale, de fapt ea își propune să le tempereze și să le direcționeze. În plan juridic, art. 53 din Constituţie ne spune că pe durata stării de urgență se limitează unele drepturi individuale. Scopul acestei limitări este acela de a permite societății ca un tot unitar să se salveze în această situație excepțională și să poată reveni la ritmul normal cât mai repede. Unul dintre sloganurile din ultimele zile surprinde tocmai acest obiectiv: „Nu există salvare individuală”!

Materialul a fost publicat în revista online a Facultății de Drept, $\underline{\text { AUBD - Forum Juridic nr. }}$ $\underline{1 / 2020 .}$

29 Comunicatul Ministerului Afacerilor Interne este disponibil la adresa https://www.agerpres.ro/social/2020/03/17/despescu-la-nivel-national-sunt-accentuate-verificarile-privind-modul-incare-sunt-respectate-conditiile-de-izolare--468598. 